\title{
Differential Involvement of Protein 4.1 Family Members $D A L-1$ and NF2 in Intracranial and Intraspinal Ependymomas
}

Pratima K. Singh, M.D., David H. Gutmann, M.D., Ph.D., Christine E. Fuller, M.D.,

Irene F. Newsham, Ph.D., Arie Perry, M.D.

Departments of Pathology (PKS, CEF, AP) and Neurology (DHG), Washington University School of

Medicine, St. Louis, Missouri; and Department of Anatomy (IFN), Henry Ford Hospital, Detroit, Michigan

Ependymomas are malignant CNS neoplasms with highly variable biologic behavior, including a generally better prognosis for intraspinal tumors. Inactivation of the NF2 gene on $22 q 12$ and loss of its protein product, merlin, have been well documented in subsets of meningiomas and ependymomas. $D A L-1$, a related tumor suppressor and protein 4.1 family member on 18p11.3, has also been recently implicated in meningioma pathogenesis, though its role in ependymoma remains unknown. Therefore, we evaluated 27 ependymomas (12 intracranial and 15 spinal) using fluorescence in situ hybridization (FISH) and immunohistochemistry (IHC) to determine $N F 2 /$ merlin and $D A L-1 / \mathrm{DAL}-1$ status at the DNA and protein levels. Demonstrable $N F 2$ and $D A L-1$ gene deletions were each detected in 6 (22\%) ependymomas. All 5 merlin losses by IHC occurred in spinal ependymomas $(P=.047)$, whereas 5 (71\%) DAL-1-negative cases were intracranial $(P=.185)$. The former result is consistent with prior observations that NF2 mutations are generally limited to spinal ependymomas. In contrast to meningiomas, simultaneous merlin and DAL-1 losses were not encountered. Our findings suggest that (1) NF2 and DAL-1 losses are involved in the pathogenesis of spinal and intracranial ependymoma subsets, respectively and (2) given the number of cases with no demonstrable losses, other cellular perturbations must also be critical for tumorigenesis.

Copyright (C) 2002 by The United States and Canadian Academy of Pathology, Inc.

VOL. 15, NO. 5, P. 526, 2002 Printed in the U.S.A.

Date of acceptance: January 8, 2002

Supported in part by grants from the National Institutes of Health (NS/ CA41520 to DHG) and National Cancer Institute (CA777300 to IFN).

These findings were presented in part at the Annual ASCP/CAP Fall Meeting in Philadelphia, PA, October 20-23, 2001.

Address reprint requests to: Arie Perry, M.D., Division of Neuropathology, Box 8118, Washington University School of Medicine, 660 South Euclid Avenue, St. Louis, MO 63110-1093; e-mail: aperry@pathbox.wustl.edu; fax: 314-362-4096.
KEY WORDS: Brain tumor, DAL-1, Ependymoma, Glioma, NF2, Tumor suppressor gene.

Mod Pathol 2002;15(5):526-531

Ependymomas are glial tumors thought to arise from primitive ependymal or subependymal cells in the vicinity of the ventricles and remnants of the central spinal canal $(1,2)$. Although they constitute only $5 \%$ of all neuroepithelial tumors, they are the third most common brain tumor in the pediatric age group. In children, the vast majority of ependymomas are intracranial and are associated with frequent recurrences, whereas in adults more then half are intraspinal, and recurrence is rarer (3). The World Health Organization (WHO) divides ependymal tumors into conventional (WHO Grade II) and anaplastic (WHO Grade III) categories, with a WHO Grade I designation reserved for two distinctively indolent subtypes, subependymoma and myxopapillary ependymoma (2). Unfortunately, histologic classification has thus far proven to be an unreliable predictor of clinical behavior, with primary tumor location and extent of resection remaining the most meaningful prognostic determinants.

In comparison to diffuse astrocytomas and oligodendrogliomas, relatively little is known about the molecular pathogenesis of ependymomas. The most frequent abnormality reported to date is deletion of chromosome 22 (4-13). Gains of chromosome 7 and losses involving chromosomes $6,9,11$, and $13 q$ have also been identified $(10,11,14-16)$. Given the increased frequency of intramedullary ependymomas in neurofibromatosis 2 (NF2) patients, it is interesting that chromosome 22 deletions and NF2 (22q12) gene mutations have been encountered primarily in spinal ependymomas (13, 17-20).

$D A L-1$ (Differentially expressed in Adenocarcinoma of the Lung), a related tumor suppressor gene on chromosome 18p11.3, has recently been identified $(21,22)$. As its name implies, this gene was 
originally identified from studies on non-small cell carcinomas of the lung but has since been implicated in the tumorigenesis of breast cancer and glioblastomas as well (22). Like NF2, DAL-1 is a member of the Protein 4.1 superfamily, and alterations of both genes have been implicated in the pathogenesis of meningiomas $(23,24)$. Given the homology between these two genes, we set out to better define the pathogenic roles of NF2 and $D A L-1$ in ependymoma. Our results suggest preferential loss of merlin in spinal ependymomas and DAL-1 in intracranial ependymomas.

\section{MATERIALS AND METHODS}

\section{Patient/Tumor Cohort}

Surgical specimens from ependymomas resected between 1990 and 2000 were retrieved from the files of the Lauren V. Ackerman Laboratory of Surgical Pathology at the Washington University Medical Center, St. Louis, Missouri. All available slides were reviewed, and a representative paraffin block was selected per case for further study. Five-micronthick sections were cut and mounted on poly-Llysine-coated slides for fluorescence in situ hybridization (FISH) and immunohistochemistry (IHC). Clinical records were reviewed for evidence of neurofibromatosis Type 2 (NF2), and National Institutes of Health diagnostic guidelines were applied $(25,26)$.

\section{Immunohistochemistry}

Slides were stained using automated $\mathrm{IHC}$ with a DAKO autostainer (DAKO, Carpenteria, CA) as described elsewhere (24). Affinity-purified rabbit polyclonal antibodies against merlin (WA30) and DAL-1 (3A1) were each applied at 1:500 dilutions, and antigen retrieval was achieved using $0.4 \%$ pepsin in $0.01 \mathrm{~N} \mathrm{HCl}$ for 30 minutes at $37^{\circ} \mathrm{C}$. Positive controls for merlin and DAL-1 included biopsy specimens of sural nerve. Study cases were considered positive if $>1 \%$ of neoplastic cells displayed cytoplasmic staining. Positivity seen only at tissue edges was considered artifactual, and therefore, a given case was considered negative if no staining was seen centrally within the tumor section.

\section{Fluorescence In Situ Hybridization}

Dual-color FISH experiments were performed as previously reported (27). After deparaffinization, the sections were subjected to target retrieval by steam cooking in citrate buffer for 20 minutes, followed by a 20-minute cool-down period and a 5 -minute wash (distilled water). This was followed by pepsin $(4 \mathrm{mg} / \mathrm{mL})$ digestion at $37^{\circ} \mathrm{C}$ for $30 \mathrm{~min}$ utes. The slides were then washed in $2 \times$ standard saline citrate (SSC) and allowed to air dry. A fluorescein-labeled P1-derived probe targeting the $D A L-1$ gene (21) and a rhodamine-labeled cosmidderived NF2 probe cocktail (donated by Dr. Mia MacCollin, Massachusetts General Hospital, Boston, MA) were paired for each hybridization. The probes were diluted in DenHyb hybridization buffer (Insitus Biotechnologies, Albuquerque, NM) at a concentration of 1:50. The hybridization mix (10 $\mu \mathrm{L}$ per slide) was applied to the sections, followed by simultaneous denaturing of probe and target at $90^{\circ} \mathrm{C}$ for 13 minutes. Overnight hybridization at $37^{\circ} \mathrm{C}$ took place in a humidified chamber. Posthybridization washes in $50 \%$ formamide/1 $\times$ SSC (5 minutes) and $2 \times$ SSC (5 minutes) were performed at room temperature, and the slides were again allowed to air dry. DAPI $(0.5 \mu \mathrm{L} / \mathrm{mL}$; Insitus Laboratories) was used as a nuclear counterstain, and the sections were viewed under an Olympus BX60 fluorescent microscope with appropriate filters (Olympus, Melville, NY).

Sections showing sufficient hybridization efficiency ( $>90 \%$ nuclei with signals) were evaluated, with 100-200 intact nonoverlapping nuclei scored for the number of fluorescent signals. Cutoffs for abnormalities or deletions were based on counts from nonneoplastic control specimens (temporal lobectomy specimens for seizure control) for each probe. Interpretation of deletion required $>50 \%$ of nuclei containing one NF2 or DAL-1 signal (mean + 3 standard deviations in controls). Because nuclei with more than two signals were rarely seen in nonneoplastic controls, polysomies (gains) were arbitrarily defined as $>5 \%$ nuclei containing three or more signals.

\section{Statistical Methods}

Associations between deletion frequencies (NF2 or DAL-1) and tumor location (intracranial or intraspinal) were evaluated based on results of the Fisher's exact test. Reported $P$ values of $<.05$ were considered statistically significant.

\section{RESULTS}

The study cohort consisted of 27 cases. Patient and tumor characteristics, as well as FISH and IHC results, are summarized in Table 1 . There were 15 spinal ependymomas, including one in the cervicomedullary junction. The intracranial tumors included nine posterior fossa and three supratentorial ependymomas. The median age for the entire group was 27 years (range, 1-72), and none of the patients had clinical evidence of NF2. However, spinal ependymomas presented at a median age of 40 years, in comparison to intracranial examples, which presented at a median age of 9 years. The 15 


\begin{tabular}{|c|c|c|c|c|c|c|c|}
\hline Case No. & Age (y)/Sex & Diagnosis & Site & $N F 2$ & Merlin & $D A L-1$ & DAL-1 \\
\hline 1 & $15 / F$ & $\mathrm{E}$ & Spinal & Polysomy & + & Polysomy & + \\
\hline 2 & $44 / \mathrm{F}$ & $\mathrm{E}$ & Spinal & Deleted & + & Polysomy & + \\
\hline 3 & $16 / F$ & MPE & Spinal & Polysomy & + & Polysomy & + \\
\hline 4 & $41 / \mathrm{F}$ & $\mathrm{E}$ & Spinal & Normal & - & Polysomy & + \\
\hline 5 & $38 / F$ & $\mathrm{E}$ & $\mathrm{CMJ}$ & Deleted & - & Normal & + \\
\hline 6 & $65 / \mathrm{M}$ & $\mathrm{E}$ & Spinal & Deleted & - & Polysomy & + \\
\hline 7 & $33 / F$ & MPE & Spinal & Polysomy & + & Deleted & - \\
\hline 8 & $56 / \mathrm{M}$ & $\mathrm{E}$ & Spinal & Deleted & + & Deleted & - \\
\hline 9 & $25 / F$ & MPE & Spinal & Normal & + & Polysomy & + \\
\hline 10 & $13 / F$ & $\mathrm{E}$ & Spinal & Polysomy & - & Polysomy & + \\
\hline 11 & $53 / \mathrm{M}$ & $\mathrm{E}$ & Spinal & Normal & + & Polysomy & + \\
\hline 12 & $28 / \mathrm{M}$ & $\mathrm{E}$ & Spinal & Polysomy & + & Polysomy & + \\
\hline 13 & $40 / \mathrm{M}$ & MPE & Spinal & NI & + & NI & + \\
\hline 14 & $69 / F$ & $\mathrm{E}$ & Spinal & Polysomy & + & Normal & + \\
\hline 15 & $44 / \mathrm{F}$ & MPE & Spinal & Deleted & - & Normal & + \\
\hline 16 & $1 / \mathrm{M}$ & $\mathrm{E}$ & Post. Fossa & Normal & + & Deleted & - \\
\hline 17 & $5 / \mathrm{M}$ & $\mathrm{AE}$ & Post. Fossa & Polysomy & + & Polysomy & + \\
\hline 18 & $9 / \mathrm{F}$ & $\mathrm{AE}$ & Cerebral & Polysomy & + & Polysomy & + \\
\hline 19 & $27 / \mathrm{M}$ & $\mathrm{AE}$ & Cerebral & $\mathrm{NI}$ & + & NI & - \\
\hline 20 & $44 / \mathrm{M}$ & $\mathrm{E}$ & Post. Fossa & Polysomy & + & Polysomy & + \\
\hline 21 & $9 / \mathrm{M}$ & $\mathrm{AE}$ & Post. Fossa & Polysomy & + & Deleted & - \\
\hline 22 & $22 / \mathrm{M}$ & $\mathrm{E}$ & Post. Fossa & Normal & + & Polysomy & + \\
\hline 23 & $18 / \mathrm{M}$ & $\mathrm{E}$ & Cerebral & Normal & + & Polysomy & + \\
\hline 24 & $2 / \mathrm{M}$ & $\mathrm{E}$ & Post. Fossa & Deleted & + & Deleted & + \\
\hline 25 & $7 / \mathrm{M}$ & $\mathrm{AE}$ & Post. Fossa & Normal & + & Deleted & - \\
\hline 26 & $2 / \mathrm{M}$ & $\mathrm{AE}$ & Post. Fossa & Polysomy & + & Polysomy & - \\
\hline 27 & $72 / \mathrm{F}$ & $\mathrm{E}$ & Post. Fossa & Polysomy & + & Polysomy & + \\
\hline
\end{tabular}

Dx, diagnosis; E, ependymoma; MPE, myxopapillary ependymoma; AE, anaplastic ependymoma; CMJ, cervicomedullary junction; Post. Fossa, posterior fossa; NI, noninformative.

spinal tumors included 5 myxopapillary (WHO Grade I) and 10 conventional ependymomas (Grade II), whereas the intracranial tumors included 6 Grade II and 6 anaplastic (Grade III) ependymomas. Therefore, intracranial cases were associated with younger age and higher grade than were spinal tumors.

Representative FISH hybridizations and immunostains are illustrated in Figure 1. FISH analysis was interpretable in 25 cases (93\%), with two cases considered noninformative because of inadequate signal intensities. FISH and IHC were concordant in $20(80 \%)$ cases for NF2/merlin and $23(92 \%)$ cases for $D A L-1 / \mathrm{DAL}-1$, at the DNA and protein levels, respectively. Losses of NF2 and/or its protein product merlin were identified in 8 cases $(30 \%)$, with NF2 gene deletion detected in 6 and loss of merlin expression by IHC in 5. Losses of $D A L-1 /$ DAL-1 were similarly found in 8 cases (30\%), with gene deletions and immunohistochemical losses, each in 7 tumors. Only two cases (Cases 8 and 24) demonstrated codeletion of both genes, and none harbored simultaneous losses of both proteins by IHC. Involvement by at least one of these Protein 4.1 family members was evident in 13 (48\%) cases overall. By FISH, polysomies or chromosomal gains were also common, encountered in 12 cases (48\%) for $22 q, 16(64 \%)$ for $18 p$, and $19(76 \%)$ for either one or the other. Percentages of polysomic cells ranged from 6 to $65 \%$ in individual cases, though most fell in the $15-30 \%$ range.
When clinicopathologic features were taken into consideration, tumor localization trends for gene and protein losses were identified (Table 2). For instance, all five ependymomas with merlin loss were intraspinal $(P=.047)$, as were 5 of $6(83 \%)$ tumors with $N \bar{F} 2$ deletion by FISH. Similarly, 5 of 7 (71\%) tumors with DAL-1 loss by IHC and 4 of 6 $(67 \%)$ deletions by FISH occurred in intracranial ependymomas. Of these observations, only the association with merlin loss reached statistical significance. However, this is most likely due to the small sizes of the groups being compared. Of the five myxopapillary ependymomas, examples of NF2 and DAL-1 losses were encountered in one case each. DAL- 1 losses were encountered in 4 of 6 anaplastic ependymomas, none of which harbored NF2 alterations. However, all six cases were also intracranial.

\section{DISCUSSION}

A variety of numerical and structural chromosomal abnormalities have been described in association with ependymomas, including those involving chromosomes $1,5,6,7,9,11,12,13,17$, and 20 (10, 11, 14-16). However, most common are chromosome 22 losses and deletions and mutations involving the NF2 tumor suppressor gene at $22 \mathrm{q} 12$ $(4-11,13)$, the latter finding ranging from $30-71 \%$ $(11,14-16)$. The NF2 tumor suppressor gene is a member of the Protein 4.1 superfamily, a group of 

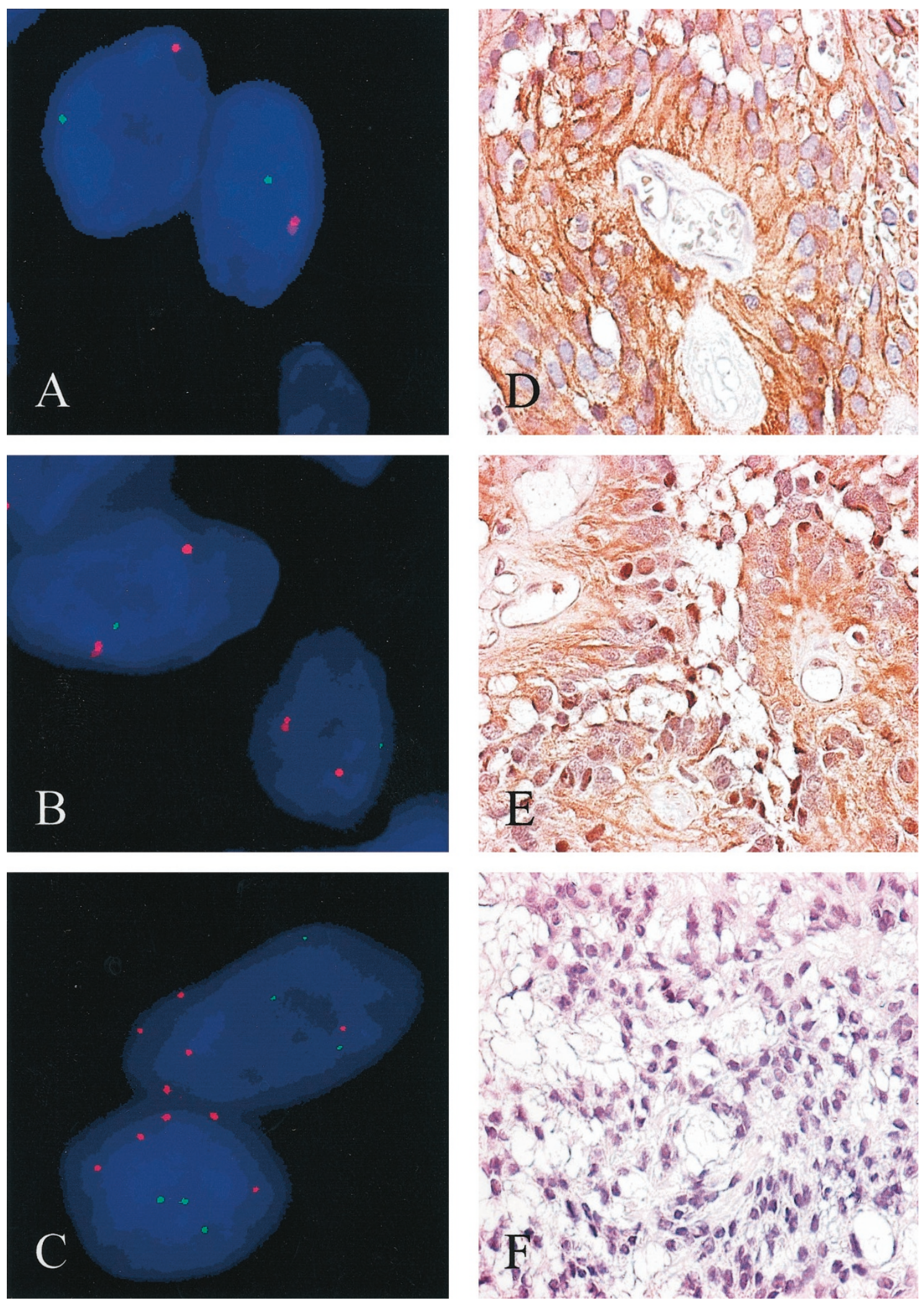

FIGURE 1. Representative FISH hybridizations and immunohistochemistry results. Dual-color FISH with green $D A L-1$ and red $N F 2$ signals demonstrate deletions for both in (A), DAL-1 deletion with normal NF2 in (B), and polysomies (gains) for both regions in (C). Strong cytoplasmic immunoreactivity for DAL-1 and merlin proteins are demonstrated in (D) and (E), respectively, whereas the case in (F) illustrates loss of merlin expression.

functionally related proteins with homologous transmembrane protein-binding domains. The newest member, $D A L-1$, was initially implicated in non- small cell carcinomas of the lung and has been associated with additional malignancies, including gliomas (22). We have recently found that similar to NF2, 
TABLE 2. DAL-1 and NF2 Status According to Site of Disease

\begin{tabular}{lcccc}
\hline & $\begin{array}{c}\text { Merlin } \\
\text { Loss (\%) }\end{array}$ & $\begin{array}{c}\text { NF2 } \\
\text { Deletion (\%) }\end{array}$ & $\begin{array}{c}\text { DAL-1 } \\
\text { Loss (\%) }\end{array}$ & $\begin{array}{c}\text { DAL-1 } \\
\text { Deletion (\%) }\end{array}$ \\
\hline Intracranial & 0 & 9 & 42 & 36 \\
Intraspinal & 33 & 36 & 13 & 14 \\
$P$ value & 0.047 & 0.180 & 0.185 & 0.350 \\
\hline
\end{tabular}

losses of $D A L-1$ are common in both sporadic and NF2-associated meningiomas $(23,24,28)$. Given that NF2 patients are also susceptible to ependymomas and that the NF2 gene has been implicated in spinal examples, we assessed both Protein 4.1 members, hoping to elucidate their roles in the pathogenesis of ependymomas.

Similar to other investigators (20), we found that NF2 losses were highly associated with spinal localization. At the protein level, this reached statistical significance $(P=.047)$, whereas at the DNA level, this was only a trend $(P=.180)$. In contrast, $D A L-1$ losses were much more common in intracranial examples, though these associations did not quite reach statistical significance, likely because of the small sample sizes being analyzed. Furthermore, simultaneous losses of both proteins were not encountered, like they have been in meningiomas (24), suggesting that there truly is a preferential inactivation of one or the other Protein 4.1 family member, depending on the site of diseâse. Larger studies will be necessary to confirm these localization trends, though this provides additional evidence for the innate differences between ependymomas at these two sites. It has long been known that spinal ependymomas behave more favorably than their intracranial counterparts. Whether or not the preferential involvement of Protein 4.1 members, in part, underlies these differences will also require further study. As in other series, we found that our intracranial ependymomas tended to present in younger patients and were higher grade on average, perhaps further accounting for biologic differences. Lastly, spinal ependymomas are significantly more accessible surgically than intracranial examples, and this increased resectability surely factors into the favorable prognosis as well.

The concordance rates between FISH and IHC were fairly high, given that one is based on DNA copy number and the other, on protein expression. Nevertheless, a number of potential explanations may account for individual discrepancies. For example, deletions of chromosome 22 often involve the entire chromosome, and therefore, cases with hemizygous NF2 deletion and retained merlin expression may reflect the involvement of another chromosome 22 tumor suppressor gene. This possibility has also been suggested by prior investigators, who have encountered $22 \mathrm{q}$ loss of heterozy- gosity (LOH) in intracranial tumors lacking NF2 mutations $(13,20)$. On the basis of careful examination of familial cases, Hulsebos and colleagues (12) have recently suggested a second ependymoma gene between 22pter and 22q11.2. Alternatively, cases with protein loss and no detectable deletion may simply represent gene inactivation by another mechanism, beyond the resolution of FISH. Examples of the latter include mitotic recombination, intragenic mutations, and epigenetic phenomena, such as promoter region hypermethylation. This may well be the case with $D A L-1$, as alterations involving chromosome 18 are not on the list of previously described abnormalities in ependymomas. Of course, technical failures and misinterpretations are always a concern, and one should emphasize that although IHC had stronger associations with tumor localization in this study, cases with patchy or weak staining are often difficult to interpret, and FISH is a more objective and quantitative assessment.

Despite the associations of $D A L-1$ and NF2 with ependymomas in this and other studies, one is struck by the fact that many cases show no evidence for inactivation of either. This suggests that there are still critical ependymoma-associated genes yet to be identified. It will be interesting to see whether other Protein 4.1 molecules, including Proteins $4.1 \mathrm{G}, 4.1 \mathrm{~N}$, and $4.1 \mathrm{R}$ are involved in ependymoma pathogenesis, though other cellular pathways are almost certainly involved as well. As in classic cytogenetic studies, we found a high percentage of our cases with polysomies or chromosomal gain. In fact, polysomy for either NF2 or $D A L-1$ was detected by FISH in $76 \%$ of our cases. As specific gains of chromosomes 18 and 22 have only rarely been detected in ependymomas by conventional cytogenetics and comparative genomic hybridization $(14,29)$, the current findings may reflect the increased sensitivity of FISH in detecting smaller alterations then either of these techniques. Another possibility is that this may simply represent an epiphenomenon in association with aneuploidy or polyploidy. Interestingly, some of the most indolent forms of ependymoma seem to harbor the greatest number of chromosomal gains (30), a finding that is seemingly at odds with the presumed progression-associated genomic instability that leads to such states of aneuploidy. In any case, it highlights how little we still know about the molecular pathogenesis of these unusual neoplasms.

In conclusion, we have provided further evidence for the involvement of Protein 4.1 family members in the pathogenesis of ependymomas. Our data suggest that there is preferential inactivation of NF2 in spinal and $D A L-1$ in intracranial ependymomas. However, the frequency of cases without loss of 
either protein suggests that other critical genetic alterations are also important and have yet to be identified.

Acknowledgments: The authors are grateful to Mrs. Pros Amargo for her expert assistance with the immunohistochemistry and to Dr. Mia MacCollin from the Massachusetts General Hospital for donating cosmid probes localizing to the NF2 gene.

\section{REFERENCES}

1. Burger PC, Scheithauer BW. Tumors of the central nervous system. Atlas of tumor pathology. 3rd ed. Washington, DC: Armed Forces Institute of Pathology; 1994.

2. Kleihues P, Cavenee WK. World Health Organization classification of tumours. Pathology and genetics of tumours of the nervous system. Lyon, France: IARC Press; 2000.

3. McLaughlin MP, Marcus RB Jr, Buatti JM, McCollough WM, Mickle JP, Kedar A, et al. Ependymoma: results, prognostic factors and treatment recommendations. Int J Radiat Oncol Biol Phys 1998;40:845-50.

4. Jenkins RB, Kimmel D, Moertel CA, Schultz CG, Scheithauer BW, Kelly PJ, et al. A cytogenetic study of 53 human gliomas. Cancer Genet Cytogenet 1989;39:253-79.

5. Stratton MR, Darling J, Lanton PL, Cooper CS, Reeves BR. Cytogenetic abnormalities in human ependymomas. Int $\mathrm{J}$ Cancer 1989;44:579-81.

6. Weremowicz S, Kupsky WJ, Morton CC, Fletcher JA. Cytogenetic evidence for a chromosome 22 tumor suppressor gene in ependymoma. Cancer Genet Cytogenet 1992;61:193-6.

7. Rubio MP, Correa KM, Ramesh V, MacCollin MM, Jacoby LB, von Deimling A, et al. Analysis of the neurofibromatosis 2 gene in human ependymomas and astrocytomas. Cancer Res 1994;54:45-7.

8. Bijleveld EH, Voesten AM, Troost D, Westerveld A, Merel P, Thomas G, et al. Molecular analysis of genetic changes in ependymomas. Genes Chromosom Cancer 1995;13:272-7.

9. Wernicke C, Gundula T, Lozanova T, Vogel S, Kintzel D, Janisch W, et al. Involvement of chromosome 22 in ependymomas. Cancer Genet Cytogenet 1995;79:173-8.

10. von Haken MS, White EC, Daneshvar-Shyesther L, Sih S, Choi E, Kalra R, et al. Molecular genetic analysis of chromosome arm 17p and chromosome arm 22q DNA sequences in sporadic pediatric ependymomas. Genes Chromosom Cancer 1996;17:37-44.

11. Hamilton RL, Pollack IF. The molecular biology of ependymomas. Brain Pathol 1997;7:807-22.

12. Hulsebos TJM, Oskam NT, Bijleveld EH, Westerveld A, Hermsen MA, van den Ouweland AMW, et al. Evidence for an ependymoma tumour suppressor gene in chromosome region 22pter-22q11.2. Br J Cancer 1999;81:1150-4.

13. Lamszus K, Lachenmayer L, Heinemann U, Kluwe L, Finckh $\mathrm{U}$, Hoppner W, et al. Molecular genetic alterations on chromosomes 11 and 22 in ependymomas. Int J Cancer 2001;91: 803-8.

14. Mazewski C, Soukup S, Ballard E, Gotwals B, Lampkin B. Karyotype studies in 18 ependymomas with literature review of 107 cases. Cancer Genet Cytogenet 1999;113:1-8.

15. Ransom DT, Ritland SR, Kimmel DW, Moertel CA, Dahl RJ, Scheithauer BW, et al. Cytogenetic and loss of heterozygosity studies in ependymomas, pilocytic astrocytomas, and oligodendrogliomas. Genes Chromosom Cancer 1992;5:348-56.

16. Zheng P, Pang JC, Hui AB, Ng H. Comparative genomic hybridization detects losses of chromosomes 22 and 16 as the most common recurrent genetic alterations in primary ependymomas. Cancer Genet Cytogenet 2000;122:18-25.

17. Pollack IF, Mulvill JJ. Neurofibromatosis 1 and 2. Brain Pathol 1997;7:823-36.

18. Lee M, Rezai AR, Freed D, Epstein FJ. Intramedullary spinal cord tumors in neurofibromatosis. Neurosurgery 1996;38: $32-7$.

19. Birch BD, Johnson JP, Parsa A, Desai RD, Yoon JT, Lycette CA, et al. Frequent type 2 neurofibromatosis gene transcript mutations in sporadic intramedullary spinal cord ependymomas. Neurosurgery 1996;39:135-40.

20. Ebert C, von Haken M, Meyer-Puttlitz B, Wiestler OD, Reifenberger G, Peitsch T, et al. Molecular genetic analysis of ependymal tumors: NF2 mutations and chromosome $22 \mathrm{q}$ loss occur preferentially in intramedullary spinal ependymomas. Am J Pathol 1999;155:627-32.

21. Tran YK, Bogler O, Gorse KM, Wieland I, Green MR, Newsham IF. A novel member of the NF2/ERM/4.1 superfamily with growth suppressing properties in lung cancer. Cancer Res 1999;59:35-43.

22. Tran Y, Benbatoul K, Gorse K, Rempel S, Futreal A, Green M, et al. Novel regions of allelic deletion of chromosome 18p in tumors of the lung, brain, and breast. Oncogene 1998;17: 3499-505.

23. Gutmann DH, Donahoe J, Perry A, Lemke N, Gorse K, Kittinitom K, et al. Loss of DAL-1, a protein 4.1-related tumor suppressor, is an important early event in the pathogenesis of meningiomas. Hum Mol Genet 2000;9(10):1495-500.

24. Perry A, Cai DX, Scheithauer BW, Swanson PE, Lohse CM, Newsham I, et al. Merlin, DAL-1, and progesterone receptor expression in clinicopathologic subsets of meningiomas: a correlative immunohistochemical study of 175 cases. J Neuropathol Exp Neurol 2000;59(10):872-9.

25. Neurofibromatosis Conference Statement. National Institutes of Health Consensus Development Conference. Arch Neurol 1988;45:575-8.

26. Gutmann DH, Aylsworth A, Carey JC, Korf B, Marks J, Pyeritz $\mathrm{RE}$, et al. The diagnostic evaluation and multidisciplinary management of neurofibromatosis 1 and neurofibromatosis 2. JAMA 1997;278:51-7.

27. Bruch LA, Hill A, Cai DX, Levy BK, Dehner LP, Perry A. A role for FISH detection of chromosome $22 q$ dosage in distinguishing atypical teratoid/rhabdoid tumors from medulloblastoma/central primitive neuroectodermal tumor. Hum Pathol 2001;32:156-62.

28. Perry A, Giannini C, Raghavan R, Scheithauer BW, Banerjee $\mathrm{R}$, Margraf L, et al. Aggressive phenotypic and genotypic features in pediatric and NF2-associated meningiomas: a clinicopathologic study of 53 cases. J Neuropathol Exp Neurol 2001;60:994-1003.

29. Reardon DA, Entrekin RE, Sublett J, Ragsdale S, Li H, Boyett $\mathrm{J}$, et al. Chromosome arm 6q loss is the most common recurrent autosomal alteration detected in primary pediatric ependymoma. Genes Chromosom Cancer 1999;24:230-7.

30. Scheil S, Bruderlein S, Eicker M, Herms J, Herold-Mende C, Steiner $\mathrm{H}-\mathrm{H}$, et al. Low frequency of chromosomal imbalances in anaplastic ependymomas as detected by comparative genomic hybridization. Brain Pathol 2001;11:133-43. 